\title{
VIOLENCE IN LATE MEDIEVAL CASTILE: THE CASE OF THE RIOJA
}

\author{
Teófilo F. Ruiz \\ Brooklyn College - University of New York
}

RESUMO: Através do uso de estudos de casos e đa análise micro-histórica, esse artigo tenta relacionar a violência da realeza e da nobreza dentro do contexto da crise de Castcla na Baixa Idade Média. Ao mesmo tempo, o artigo procura levantar questōes relativas aos métodos de resistência e mostrar como os camponeses resistiram aos ataques da nobreza e negociaram suas relaçōes conflituosas com os poderosos.

ABSTRACT: Through the use of case studies and micro-historical analysis, this article attempts to place royal and noble violence within the context of Castile's late medieval crisis. At the same time, the article tries to raise questions as methods of resistance and to show how peasants resisted noble attacks and negotiated their conflictive relations with the powerful.

PALAVRAS.CHAVE: Violência, Poder, Castela, Rioja, Idade Média.

KEY-WORDS: Violence, Power, Castile, Rioja, Middle Ages.

Many years ago, Johan Huizinga, opened his suggestive and delightful book, The Waning of the Middle Ages, with a chapter on the "violent tenor" of late medieval life. Huizinga's aim in those opening pages was to show how violence permeated the fabric of medieval life and, through colorful examples, to explore its local manifestations. Unfortunately, The Waning of the Middle Ages describes a specific region, the area of northern France and Flanders and does not draw an equally vivid portrait of the rest of European society (HUIZINGA, 1954).
Since Huizinga's great work in 1924, historians have examined manifestations of violence elsewhere in western Europe and their impact on the structures of everyday life (RUGGEIRO, 1980; NIRENBERG, 1996). In that context, I have made in my recent book, Crisis and Continuity, numerous references to violence as one of the pervasive elements of Castilian late medieval life (RUIZ, 1994). In this article, I would like to chart this breakdown of civic order in greater detail and attempt to estimate its impact on the economic and social structures of northem Castile. 


\section{Introduction}

What we witness in the period after the conquest of Seville can be described as the institutionalization of noble and royal violence. Official and private violence and lawlessness were, in part, the consequences of population decline and the concomitant reduction in available tax income. At the same time, violence, both official and private, served as a catalyst for the further recrudescence of the late medieval crisis. Unlike France, England or Italy, however, Castilian peasants, artisans and bourgeoisie seldom took arms to avenge those crimes and abuses of which they were so often the unwilling victims. Or, at least, if they resisted, they did not do so in ways with which we are familiar for other parts of Europe. There were no great outbursts of resistance. There was no Jacquerie, no Ciompi, no 1381 Peasant rebellion. The reasons why this was so complex indeed. Elsewhere I have already suggested some explanations for this passivity; in this pages, however, I will limit myself to examining the nature of the abuses and their relation to the changes which occurred in Castilian society in the century after 1248 (RUIZ, 1991, 1994b).

\section{The Violent Tenor of Life in Late Medieval Castile}

In the late Middle Ages, the anarchic and blind exercise of private vengeance, excesses by the nobility, royal greed and cruelty reached that crossroads at which, often, the normal and traditional avenues of arbitration and litigation were rendered useless (HUIZINGA, 1954, pp. 9-30)'. In thirteenth and early fourteenth century Castile, one

1. Huizinga, The Waning of the Middle Ages, pp. 9-30 and elsewhere provides an eloquent description of the "violent tenor" of society. In Castile itself, the violence of the thirteenth and fourteenth century pales when compared to the anarchy and civil conflicts of most of the fifteenth century. finds a rather paradoxical situation. On the one hand, the slow acceptance and growing familiarity with a sophisticated and ancient legal tradition (Roman law) led to the acceptance of Roman legal procedures - even if only as a supplementary code - in 1348. On the other hand, savage punishments were dealt to lawbreakers under the umbrella of the law, while private and official violence were often ignored or, worse yet, received royal sanction.

The cycle of violence extended from the king down to the lowest of his subject, including ecclesiastics as well as laymen. The kings of Castile in this period, above all Sancho IV, Alfonso XI, Peter I, Henry II, were quite willing to take matters into their own hands, to be judge, jury and executioner of their enemies and rivals. This behavior, this abandonment of every pretense of legality, this giving in to their own violent impulses was, of course, not alien to either medieval kings in earlier or later centuries nor to the society as a whole, but, surcly, in this period, the kings of France and England generally preferred their agents to carry on their dirty work while they remained safely enshrined in the dignity and mystery of their power. In Castile, however, royal personal violence was an indelible pattern, almost a ritual of passage confirming the right to rule and to power. The chroniclers report these deeds again and again, not as objectionable acts but often as corollaries to authority. In blind anger, but sometimes in cold and calculated manner, the kings of Castile struck down with their own hands rebellious magnates, princes of the blood royal and cven their own brothers (RUIZ, 1985, p. 132).

This behavior at the top set the patterns for the rest of society. The ordinances of the Cortes reveal a world quite different from the supposedly "enlightened progression of legality". As late as 1338 , at a time of shrinking resources and strife, the level of personal violence was such as to draw a great deal of attention at the important Cortes held 
that year in Burgos. The opening paragraph of the ordinances of the 1338 Cortes speaks of armed conflicts between lords, both great and small, in competition for property and vassals (Cortes, I, pp. 443-444). In an attempt to end private warfare, Alfonso $\mathrm{Xl}$ ordered the nobles and their retainers to forgive and forget all previous aggressions, condemning to death those disobeying his edict. On the other hand, the king gave license to those falsely accused and their relatives to kill (under certain circumstances) with impunity their slanderers. He also set the parameters for private challenges and duels without recourse to the law, so that "cvil men be escarmentados (taught a lesson by fear) and the rest could live in peace." Private vengeance was permitted, with royal permission, as a reprisal for the death, wounding or imprisonment of parents, grandparents, brothers, uncles or nephews (Cortes, I, pp. 444-449). These dispositions came at a time when Alfonso XI had supposedly held the reins of the realm firmly in his hands for thirteen years and close to a century after Alfonso X's legislative reforms. Yet, the 1330s' level of violence was most probably quite mild when compared with the rcal troubled minorities and civil wars which swept the kingdom in the mid $1280 \mathrm{~s}$, the mid $1290 \mathrm{~s}$ and carly 1300 s, the decade between 1312 and 1322 and the civil war in the 1360s. Although these periods of chaos did not even elicit royal action, we can trace their course by the plaintive complaints of the urban procurators at the meetings of the Cortes. Official and unofficial violence, perpetrated upon monasteries, municipal councils and the pcasantry, were part of every day life and will be examined below.

In the cities, physical attacks against authorities by armed gangs, which came to the meetings of the city council and stoned the proceedings, and private fights reached a level in the 1330s and 1340s which required the attention of the king. Such was the case in Burgos in the 1330s, when angry groups of disfranchised pecheros disrupted the workings of the city council. These acts of violence reflected the unequal distribution of power and wealth within the Castilian urban centers and the rising level of frustration of those below with the status quo. Royal intervention was aimed as much to stop violence as it was to protect the interests of those above. In the Ordenamiento de Alcalá de Henares, either death, exile and/or confiscation of property were meted to those guilty of murdering municipal and royal officials or disturbing the peace of the city (Cortes, I, pp. 525-526). In language reminiscent of modern arguments for the death penalty, the king reasoned that in "some citics and places in his kingdoms is the custom that whoever kills another in a fight is declared the enemy of the victim's relative and must pay omezillo (wergild), thus avoiding execution" or vendetta. Because of this, men dared to kill. Thus, the king ordered the death penalty for those who slay others in fights, unless it had been in self defense. Similar legislation giving license to husbands to kill adulterous wives and their lovers, or setting the death penalty for those fornicating with the concubine, relatives or servants of their lords reflect the Castilians' easy acquaintance with death, rape and other forms of violence, either as victims, perpetrators, or enforcers of the law (Cortes, I, pp. 529-530). At the inception of his rule in 1252, Alfonso $\mathrm{X}$, almost a century before the Ordenamiento de Alcala de Henares, set the cutting of the right hand's thumb as penalty for the making of forbidden articles, such as saddles ornamented with gold and silver. Those stealing eggs from goshawks and hawks during hatching periods would lose their right hand, and we have seen earlicr how those guilty of burning woods paid for their crimes by being thrown back into the firc (GARCÍA RAMILA, 1945, pp. 207, $213,215)$. The legislation of the period reflect vividly the violent tenor of life, but it does not illuminate the many instances of individual acts of violence and the arbitrary and biased workings of justice. Any perusal 
of the extant documents shows the unlawful nature of the age. Unfortunately, we do not have thc elaboratc judicial and/or manorial records available for other kingdoms - as for example medieval and early modern England - for which we have formidable studies of violence and of the attempts by authorities and individuals to prevent crime. Instead, one can only document a few individual cases, but one must not think, however, that these examples were cxceptional. Clues to the pervading presence of the most serious crimes can be easily seen in the universal and repeated complaints of ecclesiastical institutions against royal, noble and municipal assaults on their property and dependents. Municipal complaints ran along the same lines.

Equally revealing is the reluctance of monasteries and chapters to relinquish their rights of omezillo homicide, i.e., a tribute paid to the lord by its peasants (vasallos) and by the neighbors of a locality when someone was murdered within the jurisdiction of the community. Although cities, such as Burgos, had been exempted from this humiliating contribution as early as 1168 (MÚN̄OZ y ROMERO, 1972, pp. 267268 ), in rural villages collective responsibility for murders and redemption by payment remained alive into the fourteenth century. The monastery of San Salvador of Oña, for example, jealously retained its right of omezillo and to caloñas in many rental agreements in which it let out part of its domain in return for payments in issue or kind. The explicit reference to this right, while other obligations were either commuted or ignored, seems to point to murder as a common event in rural Oña and elsewhere in the merindad of Asturias de Santillana and, thus, cither a profitable due to be kept when other ancient customs were allowed to lapse or retained as a deterrent (albeit not a very good one) to crime ${ }^{2}$. In Burgos, the city for

2. See, for exemple, AHN. Clero, carp. 298, $n^{\prime \prime} 3$ $(28.6 .1286)$; carp. $299, n^{2} 16(28.6 .1289)$; carp. $300, n^{2} 5$ which we have the best medieval documentation in northern Castile, we can follow royal and municipal concerns with crime and punishment from the midthirteenth century on. Most of the extant information comes from royal letters, written in answer to municipal inquiries or complaints on judicial matters or requests for the softening of royal penalties. In 1263 , 1268 and 1279 , Alfonso $X$ sought to clarify the procedures to be followed and the penalties to be imposed in a variety of issues. These criminal actions included fights resulting in physical harm, cursing, verbal abuse, obscene gestures, innuendo and such serious crimes as rape. In one instance, the king was consulted on whether the penalties for saying to someone fududincul (literally, to call someone a sodomizcd individual) was to be equal to $f i d e$ (son of) fududincul. He answered in the affirmative, although one would have expected his attention to have been engaged elsewhere in 1279 , as the king prepared to do battle against his son, the Infanto Sancho, for control of the realm ${ }^{3}$. In the 1330 s, royal attention shifted to street violence with social and political undertones. The punitive legislation and royal edicts enacted during those years - and which wcre not unique to Burgos - were not intended to stop violence per se but to quell political unrest (RUIZ, 1977, pp. 26-27; RUCQUOI, 1987, pp. 294309; ASENJO, 1986, pp. 294-309).

Regardless of the nature of lawlessncss, one may envision a city, a realm, where physical aggression, heated and obscene gestures, verbal exchanges and

(13.7.1290); carp. 302, n" 21 (12.11.1296); carp. 303, n" 18 (24.2.1300) et passim. In the merindad of Asturias de Santillana, many of the villages paid ruglits of antczillo to their lords. See Bccerro II, 010-216.

3 AMB. classif. 2908 (6.8.1263); classif. 99 (25.3.1268); classif. 2917 (8.4.1279). Sancho IV confirmed these previleges on 26 May 1285. See AMB. classif. 121, and a few days afterwards ordered gambling houses in Burgos to be closed because of the violence which occured in the city and in Castil de judios: AMB. classif. 2939 (5.6.1285). 
sexual abuse were part of the very fabric of life. As to the latter form of violence, the legisiation against seduction and rape was certainly not aimed at protecting women; rather, it was designed to protect males from their wives' adultery and lustful treachery. The language of the fueros and of royal legislation was quite explicit on this point: it sought to protect the master of the household from suspected issuc or the judicial complications resulting from their wives unlawful behavior. In that sense, concubines, servant women and femalc relatives were treated, on matters of sexuality, as yet another form of property (DILLARD, 1984, pp. 170-192).

Violent death and swift reprisals must have been the stuff of everyday life. The Chronicón de Cardeña has just two laconic entries for the year 1255: one reported the flooding of the river Vena and the other the duel of six knights, three against three. They met in Burgos, the challengers killing their enemies outright (Chronicón, p. 373). Underlying the tenor of violence and the exercise of justice, however, was the undeniable fact that if one was powerful or had powerful friends, one could escape the harshness of a legal system which demanded life for life. In 1274, Don Pedro el Carretero obtained, by the intercession of the king, the release of a man accused of murder, who, as the document stated, "did not have to die" for his crime. In 1279, Antolín Fernández, a noble knight and a resident of Burgos, was charged with the murder of Pascual Miguel, a cleric in the parish of St. Peter in Burgos. He appealed his case to the Infante Don Sancho, obtaining his freedom and exemption from municipal retribution. The following year, to add insult to injury, the Infante Don Sancho exempted Antolín from taxes and from the jurisdiction of the city council of Burgos. One must assume that Antolin was one of Sancho's men, a knight who resided within the city walls, quick to anger, swift with his knife and sword, and, for all practical purposes, free from any restrain by municipal officials ${ }^{4}$. The point here is that most of the individual crimes for which there is surviving documentary evidence seem to have been committed by members of the ruling groups in society. This included murder and also breaking and entering. Such was the case of the armed robbery of the house of Rodrigo Ibáñez (a well-known moneylender, municipal official and member of the ruling clan of the Sarracíns) perpetrated by Giralt Bernalt (also a member of the Burgalese oligarchy) with the help of his relatives, Pedro Pérez and Pedro of Formallat, officials of the city council and prosperous merchants ${ }^{5}$. If we examine carefully the extant wills of the late middle ages, often times we find, besides the listing of pious donations, whole inventories of crimes and misdeeds. In one specific case, the will of Don Gonzalo Ruiz de Zúñiga, the document reveal a rather rich and ostentatious nobleman who, after a life of crime, sought to set his accounts in this world before entering the next one. His last wishes, as spelled out in his 1293 testament, requested burial in the portal of St. Paul, the church of the Dominican order in Burgos. A stone with his coat of arms and name was to mark his place of final rest. Gonzalo's fortune was considerable. It consisted of $13121 / 2$ doblas (doubloons), which were in the custody of Fray Andrés of Pamplona, 200 pounds tournois (minus 20 solidii), and thirtcen gold rings. Of the latter, seven were set with sapphires, four with emeralds, one with a ruby and the last one had a diamond. His heirs redeemed the rings for the large sum of 1,400 mrs., which provides an indication of the high cost of precious stones as well as the tendency for display among the nobility. In addition, Gonzalo Ruiz owned six cups of silver with a 20 marks of fine silver content, plus 304 1/2 doblas kept

4 AMB clasif. 2910 (16.4.1274); clasif. 2921 (11.11.1279); clasif. 2508 (8.8.1280).

5. AMB clasif. 2923 (18.11.1279). 
by the abbot of St. Paul. The testament also includes the usual requests for masses, charities and personal bequests. One should point that $1,000 \mathrm{mrs}$. were reserved for a rich cloth to cover his casket and 400 mrs. for masses for the souls of two of his squires (BALLESTEROS, 1922-1928).

From the will, one can also learn that Gonzalo Ruiz was one of the followers of the Infante Don Juan during the noble revolts of Sancho IV's reign. From the area of the Rioja and the border with Aragón to the lands of Burgos, the Infante "fue robando" (went stealing) and Gonzalo with him. Among his crimes, committed in the service of don Juan and of other princes, he listed stealing 520 sheep, one ox, 40 pigs, one carga (a measure of grain) of barley, 7 cargas of wheat, 150 fanegas of wheat and rye taken by force from a peasant, 3 mules, plus an assorted list of money (or the forced quartering expressed in issue) which he extorted from ccclesiastical institutions, village councils and individuals. This included thefts in Alvarracin for the sum of 2,000 mrs. The list continues for around half a page in the printed edition, including the burning of a house (valued at $40 \mathrm{mrs}$. near Salas ${ }^{6}$. These were the actions of a nobleman in the service of others more powerful than he was. There is no reason to think that he was anything but typical of the actions of his noble contemporaries, though the mind boggles at what gangs of knights, such as Gonzalo, could have done to the well-being and collective peacc of Castilians (VELAYOS, 1978, pp. 20-21, 6670). This was violence sanctioned by the political strife and expected in a society almost continuously at war in this period. And the disturbances of Sancho IV's reign can be considered minor when compared to those of Ferdinand IV and Alfonso XI's minorities.

Even those who were not directly engaged in the civil strife plaguing the realm thought nothing of

6. Ibidem. behaving in a violent and illegal manner. Such was the case of Lope Alvarez. His will was drawn in 1315, and it shows the casual way in which Lope took mules and others goods from clerics, peasants and shopkeepers by force or deception?. That Gonzalo Ruiz and Lope Alvarez sought to return their illicit gains (if the victims could be found and a price for compensation agreed upon) tell us a great deal about their fears of eternal damnation. The wills also tell us about lives of total disregard for the laws of men and God. At the end, of course, their repentance did little to atone for the suffering of their victims.

But violence against people and property in Burgos and elsewhere was not the exclusive monopoly of the nobility. In 1366, the lame and physically handicapped beggars of Burgos had occupied illegally the hospital for the blind set up by the city. Not content with displacing the blind from their rightful refuge, the lame and handicapped also beat the blind regularly".

When we turn from the area of Burgos to other parts of Castile, the picture does not change very much. In 1256 the citizens of Osma, in open conflict with their bishop, attacked and burned the village of Sotos de Jusos and other properties of the cathedral of Osma. As they retreated, they also took the peasants' livestock with them (CORVALÁN, 1788, pp. 84-86). Clerics themselves were as guilty of violence and misbehavior as everybody else. Peter Linehan's graphic and prurient anecdotes of ecclesiastical misconduct can be supplemented with many references to the violent behavior of the secular and regular clergy against each other and against the laity. Indeed, if the relations of the bishop and chapter of Burgos with the great monasteries of the region, Las Huelgas, Arlanza, Silos, Cardeña, is any indication, one could see how easily disputes could

7. AHN Clero, carp. 241 , no. 1 (29.4.1315).

8. ACB, vol. 44 , f. $180(2.12 .1366)$. 
turn into open aggression. Jurisdictional conflicts, issues of ecclesiastical discipline, rights of property and other questions were a recurring theme in the history of the Castilian church and of the Church at large. The Dominican monks of St. Paul in Burgos, for example, sought to build a bigger house on the banks of the Arlanzón river, beyond the city walls. Their efforts were thwarted by the hostility of the chapter and bishop, their building stones repeatedly stolen from the building site ${ }^{9}$. How monks and nuns took justice into their own hands, especially if it involved financial matters, can be easily gathered from the long dispute between the monastery of Santa María La Real de Aguilar de Campóo and Dona Mayor Alvarez over the will and disposition of the body of Ferrando Royz de Castañeda, Doña Mayor's late husband. On 5 July 1329, at the house of García Miguéllez in Valladolid, fray John, abbot of Santa María la Real de Aguilar de Campóo, appeared before García Pérez de Valladolid, alcalde of the king, Alfonso Royz, public scribc of that city, and other witnesses. He stated that Ferrand Royz de Castañeda, recently deceased, had donated to the monastery all his holdings in Cilla Mayor plus 500 $m r s$. The terms of his will also requested burial at the monastery, where Ferrand's parents had already been laid to rest. The will was in the hands of the scribe and García Pérez, the alcalde, declared it valid $^{13}$. Three and a half years later, on 6 January 1333, Alfonso Xl confirmed the decision of García Pérez de Valladolid on the litigation between the monastery and Ferrand's widow, Doña Mayor. The abbot charged the widow with refusing to relinquish the propertics in Cilla Mayor. While admitting this to bc so, doña Mayor explained that, as the funcral cortege made its way from Valladolid to Aguilar dc

9. AHN Clero, carp. 184, no. 10 (17.5.1276); carp. 185, no. 1 (5.8.1288). See Peter Linehan's forthcoming article on the disputes between the friars and the chapter.

10. AHN. Clero, carp. 1669, no. 19 (5.7.1329).
Campóo for the burial of Ferrand Royz, they passed by the monastery of Avía and the abbess and nuns stole the body and interred Ferrand in the choir of their monastery. Regardless of the final disposition of Ferrand's mortal remains, the alcalde ordered Dona Mayor to comply with the financial terms of the will. On 29 January of the same year, Dona Mayor relinquished the disputed property to fray John, the abbot of Santa María la Real de Aguilar de Campóo" ${ }^{11}$. What can be learned from this incident? The community of Santa María of Aguilar de Campóo was obviously more interested in securing the holdings in Cilla Mayor than in fulfilling its spiritual duties. As to the deeds of the nuns of St. Felices of Avía, the easiest explanation is to assume a convent in dire financial straits and hoping, by the capture and burial of Ferrand Royz's body, to gain a share in the will. Indeed, as we know from the abundant documentation on these matters, one of the most common issues of contention between monastic orders and between secular and regular clergy was precisely the right to bury those whose descendants may prove to be grateful patrons. As far as we can reconstruct the holdings of Avia, they constituted a meager domain, spread in villages nearby the monastery. It was an uneasy lordship, often shared with far more powerful monasteries or unruly lords. If the Becerro, which reflects conditions twenty years later, is accurate, the income which the monastery obtained from this domain was quite small ${ }^{12}$. On the other hand, the Castañeda family held important lordships throughout the merindades of Old Castile and ties to the family may have proved beneficial to fledgling monastic institutions. Doña Mayor, herself, was still alive in the mid-fourteenth century and held rights in the villages of Ribas and Mansiella (Mansilla de Burgos); other members of the family,

1). AHN. Clero, carp. 1670 , no. $14(6.1 .1333)$; no. 15 (29.1.1333).

12. Beccrro, I, 229-30, 238, 245, 319; II, 39. 
above all Ruy González de Castañeda, had extensive properties throughout the region ${ }^{13}$. One should also noticc how long it took for justice to be rendered. In this particular casc, it took almost four years after Ferrand Royz's death for the monks of Santa María la Real to secure the rights and income of Cilla Mayor. The story, however, ended well. Twenty years later the monastery still retained its jurisdiction over the village. Many other monasteries were not as fortunate in the troubled years of the mid-fourteenth century.

\section{Royal Violence}

The greatest scourge for both, the pcasantry and small monastic institutions, was not always the random violence of magnates and noblemen. On the whole, as painfully intrusive as they werc, magnatc excesses were localized events - even though in the casc of great families, such as the Haro, their power extcnded over a vast region. In many respects, what they took with one hand, they often either gave back or protected with the other. There was, after all, a limit to how much these noblemen could squeeze out of their peasants, or rob monasteries in which they wished to be buried. Morcover, they were not adverse to being bought. The numerous "prestamos", the granting of rights of lordship by a monastery to a lord for a lifetime without any obligation or rent, secms to indicate payments for services rendered, mostly protection, or bribes to prevent further violence. The systematic demands and abuses of royal officials, on the other hand, had an even deeper impact, for they undermined the last vestiges of law and created an atmosphere of selfish chaos in which small villages, monasteries and municipalities had to fend for themselves in often futilc attempts to protect their local interests at all costs.

13. Idcm, I, 218; Il, 284. For Ruy González de Castañeda see I, 113.15, 126-27, 131, 134, 137-40 el passim.
Beginning in the late thirteenth century, the list of protests, mostly from monasteries but also from municipalities, is almost endless. Again the bone of contention was the improper collection of taxes by royal agents and their disregard for exemptions or privileges. Clearly, the zealousness of bureaucrats in this period is certainly not peculiar to Castile. Elscwhere we turn in western medieval Europe, crown officials were energetically pushing the boundaries of royal jurisdiction with or without the direct encouragement of their kings. In Castile, however, the impression conveyed by the documents is one of royal officials seeking to extract as much as they could from their charges, while the crown did not have cither the proper information of or control over these actions. Again and again we witness royal ordinances and privileges confirmed by the king, whilc at the samc time these same privileges were disregarded by rapacious royal officials. Inquests were ordered, money was spent, letters went back and forth, and, at the end, things remained very much the way they had always been. Monasteries and their dependent villagers were often victimized, and, as often, urban dwellers were deprived of their rights.

This frantic struggle to get as much as possible from taxpayers with ever decreasing sources of income can be seen in three specific points of conflict between monasteries, municipalities and royal officials. They were: 1) the demands of the royal merinos for a monastic contribution of a mule and a silver cup; 2 ) the refusal of royal and municipal officials to pay the amounts assigned by the king to monasteries from the income of salt wells, or toll taxes; 3 ) the refusal by tax collectors to admit royal exemption from toll, customs, any other taxes and, above all, transhumance rights. Illegal taxation was often accompanied by forced expropriation of land and income, imprisonment of dependents and confiscation or outright robbery of movable goods. 
The monastic contributions of a mule and a silver cup

In the early thirteenth century, the royal merinos had received an annual gift of a mule and a silver cup from monasteries. By the second half of the thirteenth century, many monastcries had been exempted from such payment and, eventually, the tegislation of the Cortes, at the petition of prelates, ended the contribution ${ }^{14}$. Yet for all these ordinances, the demands continued. In 1309 the Cistercian abbot of the monastery of Our Lady in Bujedo (diocese of Burgos) wrote to the king describing the condition of the monastery "pobre y menguado por las guerras que passaron e los robos e por las tomas e muchos males que recibieron" (poor and diminished because of the wars just ended and the thefts, and appropriations which they [received] suffered), plcading for relief. Ferdinand IV exempted them from the payment of a mule and silver cup. In 1326 Alfonso Xl confirmed this exemption; yet, in 1338 , supposedly at the high point of Alfonso XI's power, the merinos reales were still demanding the contribution and forcing the monastery of Our Lady of Bujedo to pay them the aforementioned items ${ }^{15}$. Earlicr, in 1287, the abbot of San Pedro in Gumiel de

14. Abuses dealing with illegal appropriations of accmilas (mules) and excesses of merinos are banned in the ordinances of the Cortes, I, 189 (Valladolid, 1307), 219 (Valiadolid, 1312), 286-87 (Burgos, 1315); petitions of the prelates against the exaction of mules and silver cups by the merinos mayores and the adelantados are found in Cortes, $\mathrm{J}$, 296-97 (Burgos, 1315) el passim. Royal exemptions of contribution of mules and silver cup 10 merinos were granted to the Benedictine, Cistercian and Premontre monasteries in 1282 and 13/2: Recucil, ed. Férotin, I, 272 (21.4.1282) and p. $376(12.3 .1312)$.

15. AHN Clero, carp. 171 , no. 9 (25.3.1309), no. 10 (18.4.1326), no. 12 (18.4.1338). In 1347, Alfonso X] reduced the payment of yantar to $200 \mathrm{mrs}$. annually, because the monastery was poor: AHN Clero, carp. 171, no. 13 (26.2.1347). See also nos. 14, 15, 16 (20.2.1366 to 15.11.1371). In the latter, the monastery was even exempted from the 200 mrs.
Izán protested to Don Diego López de Haro, adelantado mayor of Castile and a favorite of Sancho IV, that the merino real of Santo Domingo de Silos was demanding a mule, silver cup and purveyance in spite of the monastery's cxemption. Thirteen years later, in the midst of a troubled minority, the situation had aggravated a great deal. By then, merinos, magnates, and other noblemen demanded mules and silver cups and, when refused, they took it by force ${ }^{16}$. There are few monasteries, from one corner of Old Castile to the other, which did not voice similar protests over the illegal exaction of mules, silver cups and purveyance. Decade after decade, the kings ordered their officials to honor the exemption, but the protests show that royal official ignored the royal orders and continued their illegal practices.

\section{Other abuses against monasteries and cities.}

Refusal to allow for legal exemptions and denial of income

In the same vein, from Avila to the Rioja, from Aguilar de Campóo to Siguenza, fonsadera and other taxes were collected illegally from the tenants of monasteries, and, we must also suppose, from those of noble lords too weak to prevent it ${ }^{17}$. Road

16. AHN Clero, carp. 233 , no. 2 (12.3.1287), no. 9 (28.12.1300).

17. Protests against the illegal collection of fonsadera can be found in the documentation of Oña. See, for example, Oña, Il, 748-49 (10.7.1275); AHN Clero, carp. 299, no. 10 (26.3.1289); carp. 302 , no. 18 (5.8.1296); carp. 306, no. 12 (30.1.1309), no. 16 (2.6.1315); carp. 311 , no. 17 (2.5.1339). Also see in Segovia, one dependant of the monastery of the Holy Cross in Segovia was excused of martiniega, but tax collectors still demanded payment: AHN Clero, carp. 1963, no. 6 (29.9.1344). Sec atso DMA, \#96 (6.1.1272); \#172 (10.7.1297); in Burgos, the bishop and the cathedral chapter often protested against the illicil attempts of royal officials to collect fonsadera and other taxes from which their dependents were exempted. See ACB vol. 78 , f. 2 (23.9.1288); vol. 17, f. 428 (10.12.1288); vol. 17, f. 433 (25.1.1340) el passim. 
tolls were also collected illegally for their goods; the rights and privileges held by monasteries and municipalities were often ignored. Thus, in $1345 \mathrm{Al}$ fonso XI acknowledged that the cathedral of Burgos was exempted from paying portazgo, and that he (the king) had not respected these privileges "because of his great [financial] need"'s.

Another way in which royal officials contributed to the state of violence and financial breakdown of the realm was by refusing to pay royal grants in either issue or kind to monasteries, or by demanding taxes above the amount agreed between crown and the ecclesiastical or municipal institutions. Thus, the royal officials at Salinas de Añana, in spite of Alfonso XI's orders, refuscd to pay the monies due to the monastery of Our Lady in Herrera in 1332 and 1333. Eight years later, after a long and taxing inquest, the monks of Herrera had not been abie to collect their rightful dues ${ }^{19}$. In 1336 Alfonso XI wrote to Ferrando Pérez de Porto Carrero, the merino mayor in Castile, ordering him not to allow royal officials to demand more than 150 mrs. in purveyance from the monks of Our Lady of Rioseco, nor to imprison the monasteries vassals as a mean of forcing payment ${ }^{2 n}$. Further east, in the region of Campóo, the nuns of San Andrés de Arroyo had been granted a miserly $36 \mathrm{mrs}$. per week from the portazgo of Aguilar de Campóo. Already by 1291 they complained that they were not receiving any of the money. In spite of numerous complaints and royal letters to the effect, for the next half a century the abbess and the monastery were not very successful in enforcing their rights. In 1326, 1327, 1330, 1332, after long and costly litigations and inquests, the

18. ACB vol. 2, part 2, f. 39 (20-V-1345). Other examples of violation of exemptions from portazgo can be found in ACB vol. 78, f. 2 (23.9.1288); AHN Clero, carp. 299 , no. 12 (12.4.1289); carp. 307 , no. 19 (6.6.1315) el passim.

19. AHN Clero, carp. 241 , no. 12 (12.8.1332); carp. 241 , no. 154.5 .1333 ); carp. 242 , no. 13 (25.5.1341).

20. AHN Clero, carp. 355 , no. 12 (1.5.1336). abbess of San Andrés still pleaded for the payment of their share of the portazgo of Aguilar, long in arrears ${ }^{21}$. For all the pious protestations of Alfonso XI or his energetic letters to municipal or royal officials, little was changed.

In Avila, in 1272 and later in 1296, the royal officials sought to collect taxes from the bishop's vassals in the villages Santa María de Mesegar, San Bartolomé and Malpartida although the peasants' obligations were to the bishop and not to the crown. In 1286, Blasco Blázquez, a royal official, attempted to exact payment for fonsadera from the parents of the forty servants of the cathedral canons, who had been exempted just a few years earlier by the king. In 1297, Ferdinand IV demanded $600 \mathrm{mrs}$ : from the bishop of Avila for purveyance, though he had been granted relief from this obligation by previous kings. Aftcr an inquest which lasted almost cight months at considerable cost, the king recognized that he did not have the right to demand yantar from the church of Avila ${ }^{22}$. Nor were the kings of Castile above direct extortion. In 1349, Alfonso XI demanded from the church of Avila a free and voluntary contribution to the sicge of Gibraltar, "because the income of his lordship was not enough". When all the money was not forthcoming, he ordered the alcaldes of the city to confiscate church property up to the amount required to complete the quantity required and to sell it to the "five or six or ten richest men in the town or villages where the propertics were located

21. The original donation of 300 mrs. annually was granted by Alfonso X: AHN Clero, carp. 1731, no. 10 (13.3.1256). Protests against the refusal to pay by royal and municipal officials and decisions of the alcaldes of Aguifar granting the 36 mrs. per week in AHN Clero, carp. 1733, no. 3 (7.1.1326), no. 4 (9.1.1326). A long inquest was recorded in AHN Cleto 1733, no. 9 (10.2.1327). Also no. 15 (15.1.1330); carp. 1734, no. 2 (24.5.1332).

22. $D M A$, pp. 86, 162-163, 118-1!9 (1286), 168-169. See also AHN. Clero, carp. 28, no. $9(23.12 .1337)$ : one of the vassals of the bishop of Avila had been extorled payment regardless of her exemption. 
(Colección de Alfonso XI, pp. 595-597). Nor was this an isolated event. In the 1340s, as the need for income grew and the resources decreased, Alfonso XI often resorted to this form of financial pressure.

We witness, thus, two types of arbitrary exactions by royal officials: those who circumvented or ignored royal exemptions, seeking to increase fiscal intake as well as fatten their own pockets, and when special circumstances or simple greed prompted the crown to demand money illegally. But Alfonso XI, in the 1340 s, only followed on patterns of extortion established by his ancestors. In 1283, the Infante Don Sancho confiscated the property of Juan Garcia de Covarrubias. This action resulted from Juan García's support for Alfonso X during the conflict between the king and his son, as well as Sancho's need for money. Soon afterwards, the Infante forced the twelve richest men in Covarrubias to purchase the confiscated lands and to pay the purchase price to him (Fuentes de Castilla II, p. 126, 14.6.1281). Although the examples are numerous and cut across the width of Castile, the extant documentation of San Salvador de Oña, a monastery north of Burgos, provide one of the most revealing examples of these illegal demands, and the problems which ecclesiastical institutions and its tenants faced under excessive and illegal demands.

\section{The Case of Oña}

In 1285, Sancho IV confirmed Alfonso X's letter forbidding noblemen in the region of Oña to purchase property from the monastery's vassals. This was often followed by their refusal to pay dues to their theoretical overlord and the subsequent loss of income for the monastery ${ }^{23}$. This was a longstanding problem, already addressed by Alfonso $X$, as indicated above, and which also plagued

23. AHN. Clero, carp. 297 , no. 1 (11.4.1285). monasteries, cathedral chapters and secular clergy throughout Castilc. Although not an example of illegal demands, the erosion of ecclesiastical domains, through the purchase by magnates, made the violation of fiscal exemptions even more painful. In 1300,1329, 1338 and 1351, the abbots of Oña complained bitterly against these purchases. In the last instance, urban oligarchs were also actively buying lands from vassals of $O \bar{n}$ a and then refusing to pay infürción to the monastery. The abbot complained that because of these actions the land became yerma ${ }^{24}$. More seriously, however, were the frequent incursions of magnates and their retinues. They entered the lands of San Salvador, robbed, burned and sometimes even confiscated outright monastic lands. These were common events; which, as the extant documentation shows, occurred throughout most of the century after 1248 and even in years which were supposedly peaceful. In 1338, the abbot and monks of Oña protested to Ferrant Pérez de Porto Carrero, merino mayor of Castile, that the magnates, noblemen and townspeople of the region were "fencing the monastery's meadows, cutting their trees, hunting their partridges, fishing their salmons and trouts"25.

Yet, how could the royal officials or even direct appeals to the kings in this period be of any use, when royal officials and even direct overlords could also be charged with the same excesses. Royal officials, Lope Díaz de Haro and his agents and before him his father, Don Diego of Haro,- took yantar (purveyance) by force from the monastery and from the monasteries vassals ${ }^{26}$. The collectors of the fonsadera, again and again, exacted the tax, often by force, from helpless villagers under the

24. AHN. Clero, carp. 303, no. 21 (11.6.1300); carp. 310 , no. 3 (15.8.1329); carp. 311 , no. 13 (5.12.1338); carp. 313 , no. 8 (27.6.1351).

25. AHN. Clero, carp. 311 , no. 11 (7.9.1338).

26. Oña, pp. 556, 583, 698-99, 722-23 et passim. 
jurisdiction of Oña throughout the century after 1248. Inquests to remedy these abuses were undertaken and such practices forbidden, but little changed ${ }^{27}$. In the same vein, the collectors of gate tolls (portazgo) exacted as much as they could from the monks of Ona, even though they had enjoyed exemption from those taxes for more than a century ${ }^{2 x}$. Regardless of royal letters confirming their privileged status, nothing was gained. The administrators and farmer of the salt wells (Salinas de Rosío), where San Salvador de Oña had been granted 300 mrs. annually in 1239 (which were the equivalent of 1,800 mrs. in the carly fourteenth century) and 412 almudes of salt, refused to pay the amount in full as they did in 1292, or refused to give anything at all as they did in 1309 and $1314^{20}$. In 1332, the collectors of the purveyance in Laredo took by force $100 \mathrm{mrs}$. from Oña's dependency of San Pelayo de Cesera and 200 mrs. from its vassals. Alfonso XI's admonitions to his official did not include, however, an order to return the monies ${ }^{30}$.

In 1312, Ferdinand IV wrote to Ferrant Royz de Saldaña, adelantado mayor in Castile, regarding complaints of the abbot of San Salvador de Oña. The castellans of the royal fortress at Frías (a few kilometcrs down the road from Oña and an important commercial link between Burgos and the ports of the Bay of Biscay) stole clothes, fire wood and meat from the vassals of the monastery, who

27. Oña, Il, 631-32; J. José García, Fucntes medicvales castcllano-lconcsas, F. Javier Peña, el al, eds. Twenty volumes published of a projected one hundred and three (Burgos, Ediciones J.M. Gartido Garrido, 1983- ) (hereafter $F M C L$ ), 4, 86.87 (26.3.1289), 210.12 (24.6.1294), 241.42 (5.8.1296); AHN. Clero, carp. 311 , no. $6(13.5 .1337) \mathrm{ct}$ passim.

28. Oña, II, 700-01, 781-82; FMCL, 4, 90-91 (20.4.1289), 134-35 (14.1.1292) et passim.

29. Oña, 1I, 489, 642-50; FMCL, 4, 136 (1292), 239 (1296); AHN. Clero, carp. 306, no. 11 (30.1.1309); carp. 307 , по. 13 (12.7.1314).

30. AHN. Clero, carp. 310 , no. 8 (11.1.1332); no. 9 (20.8.1332). because of these deeds were poor. A royal inquiry undertaken by Diego Pérez, alcalde of the king in Frías, and Lope Ruiz de Frías found the charges to be truth, and the king, therefore, forbade the castellans from continuing such abuses. Yet, three years afterwards, Alfonso XI, or his tutors, had to reissue Ferdinand IV's admonitions, showing the independence of royal officials from the crown's authority - each of them seeking to further his own ends and fortune ${ }^{31}$. The burdensome repetition of monastic complaints about official cxtortion and royal inaction does not provide the sense of immediacy and crisis which specific events do. What this official violence meant for San Salvador de Oña in terms of rents cannot be calculated, but we can sec the impact in terms of day to day life. In 1307, the abbot and monks of Ona complained to the king that their house in San Martín of Montenegro, which was rented to two good men and exempted from taxation by ancient privileges, was in danger of becoming vacant because of illegal tax demands. Although the possibility exists that these might have been land abandoned because of more attractive offers elsewhere, with the abandonment blamed on taxes or the excesses of royal agents, according to the monks no one wished to rent the property if, in addition to the customary contributions to monastery, they also had to satisfy the demands of royal officials. Ferdinand IV ordered an investigation which showed that the property was rightfully exempted; therefore, the king ordered his financial agents to ccase demanding taxes. Yet, in 1318 , two royal letters show that nothing had changed and that according to the abbot "no one wished to rent the land." 32 . Not unlike threc

31. AHN. Clero, carp. 307 , no. $5(4.7 .1312$ in a copy of 19.1.1364); no. 20 (20.7.1315).

32. AHN. Clero, carp. 306, no. 1 (16.4.1307 in a copy of 10.9.1307); carp. 308 , no. $7(12.7 .1318)$, no. 8 (24.7.1318). 
centurics afterwards, excessive taxation - most of it illegal - was slowly but inexorably crushing the northern Castilian peasantry. As shall be seen below, not different from the late sixteenth century, the peasants were voting with their feet.

\section{Fiscal oppression of municipalities}

The fiscal oppression was not limited to ecclesiastical institutions already on the decline because of changing economic conditions and a decrease in gifts from the laity; it also affected powerful municipal councils, such as Burgos and Cuéllar. In a previous chapter we have seen the conflicts over taxation and other matters erupting between the council of the town of Santo Domingo de Silos and its monastic overlord, and between townsmen and royal officials. Here we could see the bind in which municipal authorities found themselves when faced.with official rapacity:

In the late 1270 s Burgos was fined heavily for allowing money lenders to operate in the city and to collect usurious rate for their services. In 1278, the Infante Sancho had ordered two "good men" of Burgos to accompany royal officials conducting an inquiry into this matter. Once the municipal council was found guilty, Alfonso $X$ imposed a fine of 60,000 mrs. on those lending money in the Burgos at usurious rates. As one of Sancho's letters implies, these money lenders werc Christians "endangering their soul because of the sin of usury", they werc also the leading citizens of Burgos. Therefore, the city became responsible for making good on the fine. Sixty thousand mrs. was a rather stiff sum, but the Christian money lenders could have considered it an inevitable overhead in what was a very protitable enterprise. With interest rates of at least $33 \%$, the expense could be passed on to the unfortunate borrowers.

At this juncturc, however, things became a bit complicated. Alfonso $X$ and the Infante don Sancho were, by then, struggling over the rights of succession. Alfonso advanced the claims of his grandson, the Infante of La Cerda, and Sancho his own rights to the throne. In need of money and men to promote their own causes, they both sought to collect the fine from Burgos. Alfonso $X$ delegated this task on Aparicio Guillén, a Burgalese citizen and member of the ruling elite, and on Don Zag, the Jew of Don Manuel. The Infante don Sancho, in turn, assigned Miguel de Sevilla and the abbot of San Pedro de Cardeña, an important monastery 10 kilometers from Burgos, as his agents. Although the terms of the agreement are not clear, the Burgalese municipal authorities struck a bargain with the Infante whose cause they supported! An installment of 40,000 mrs. was to be paid on 1st August 1278 and the other 20,000 mrs. by the feast of St. Martin ${ }^{33}$.

Sancho's letter of 28 July 1278 reveals his pressing need for the money to pay his knights and of the use of the fine's income in the campaign to maintain his right to the thronc. Meanwhile, Alfonso $\mathrm{X}$ kept pressing Burgos for prompt payment of the fine to his own agents and forbidding the council of the city to make any payments to the Infante Sancho. In mid-August, Alfonso X's man, Bernard of Centellas, came to Burgos to collect 20,000 mrs. of the 60,000 mrs. fine for Michaelmas; but as we have seen above, Sancho had already received a commitment to that money, plus an initial payment of 40,000 mrs. half a month earlier. With Sancho's support, Burgos resisted Bernard's demands. Thus, the king made new and futile claims to the money in late September 1278, finally ordering an inquiry into the whole affair in February 1279. By then,

33. On the conflicts between Sancho and Alfonso $X$ over the usury fines see BALLESTEROS, 1946, pp. 93-194; AMB clasif. 2560 (14.5.1278); clasif. 2561 (15.7.1278); chasif. 2562 (16.7.1278); clasif. 2564 (18.7.1278), clasif. 2563 (28.7.1278). 
Sancho had received the full amount of the fine, and there was nothing left for his father and enemy ${ }^{34}$.

As if having the king and the Infante make conflicting claims on the city resources was not enough, shortly after Martinmas, the council of Burgos had to appeal to the Infante since his fine collectors continued to demand money even after the fine had been paid in toto ${ }^{35}$. Similarly, in 1284, after Sancho had promised remission of taxes to the city councils which had been loyal to him during his conflict with Alfonso X, Pedro Díaz and Muño Díaz, Sancho's tax collectors, attempted to exact 30,000 mrs. in fonsadera from Burgos although the city had been exempted from that tax since the twelfth century ${ }^{36}$.

Royal demands could be irksome and a burden for most municipalities; they did not need to involve such substantial amounts as the 60,000 mrs. in fines paid by Burgos. Beginning in 1340, the city council of Cuéllar and the crown engaged in a protracted dispute over the illegal collection of taxes. At stake was the paltry sum of $360 \mathrm{mrs}$. or the equivalent of the fonsadera obligation of twelve men. On 20 February of that year, one of Alfonso X's officials, López Ferrández, informed the concejo of Cuéllar that it should pay the fonsadera, amounting to 40,000 mrs. to Juan González de Roa, one of the king's crossbowmen and to Ferrán Pércz de Saldaña, both king's men in the dioceses of Segovia (Colección de Cuéllar, 93: 20.2.1340).

Several months later, in September 1340, the tax

34. AMB clasif. $2566(30.7 .1278)$; clasif. 2567 (8.8.1278); clasif. 2912 (14.8.1278); clasif. (22.9.1278); clasif. 2571 (16.10.1278); clasif. 2572 (20.2.1279).

35. AMB clasif. 2569 (6.10.1278): "Pesquisidores que era en ssu logar por mi en rracon de las usuras por sessaenta mill mrs delos dineros blancos de la gucrra que me dieron" (emphasis mine, that they had already given me). Sancho ordered that the property or monies taken over the agreed sum should be returned.

36. AMB clasif. 2935 (8.3.1284). had not yet been fully collected, and two new officials, Alfonso Pérez and Blasco Ferrández de Medina del Campo, were assigned to receive the monies from the tax farmers (the payment of the fonsadera had, in fact, being farmed by the city council itself). By 7 November, the concejo de Cuéllar at a public meeting made a partial payment of 18,000 mrs., hoping that they had fulfilled their obligations for the moment. Obviously, the tax farmers and collectors in the jurisdiction of Cućllar were members of the town council, had profited from collecting the tax and were themselves, most probably, exempted from it. Five days after Cućllar had formally paid its taxes to Alfonso Pérez de Medina del Campo, the king demanded an additional $360 \mathrm{mrs}$. in fonsadera from the twelve pecheros of Pedro Ferrández. Gonzalo García, García Royz, Juan González and Rodrigo Sánchez had been the actual collectors of the tax and, as their answer to the king implied, were members of Cuéllar's concejo as well. They protested that the king had previously exempted the twelve men of Pedro Ferrández, scribe of Cuéllar ${ }^{37}$.

In early January 1341 the dispute was still going on, but a long settlement on the 15th of the month seemed to have resolved the issue once and for all. Yet, in 1346 the king was still claiming the $360 \mathrm{mrs}$. which had not been paid in the fonsadera of 1340 . That year, he sent his crossbowman, Johan Descol, to collect the aforementioned sum. On 14 May 1346 , the king's envoy met in an open square with the town officials and most citizens of the town. The citizens of Cuéllar bowed to the kings' demand, but did not pay immediately because of the absence of many of the knights and squires of Cuéllar, gone to the tasks of the transhumance. It "was late", as the document states, and the flocks and many men of Cuéllar were most probably on their way to the

37. lbidem., \#98 (12.11.1340), \#99 (15.11.1340). 
summer pasture lands. A month later, however, a representative of the town traveled to the royal court to argue in front of the king that the town council did not owe $360 \mathrm{mrs}$., since Alfonso XI, himself, had exempted the twelve pecheros. At the end, the king relented and "forgave" Cuéllar its debt ${ }^{38}$.

Unlike previous examples, in this instance the concejo was able to defend its privilege, or should we say, the privileges of its ruling elite. But at what cost! To defend themselves from the illegal collection of $360 \mathrm{mrs}$. in 1340, the citizens of Cuellar had to litigate for six years, to send a procurator to the royal court, to bear the burden and threats of several visits by armed royal agents, to draw several legal instruments and to call extraordinary meetings of its council. Even when succeeding in resisting illegal fiscal demands, Cuéllar's victory was, by all accounts, a Pyrrhic one. The cure was far more expensive than the sickness.

\section{Noble Violence}

As we look across the plains of Castile, the burden of taxation and illegal royal demands in this period was a vivid example of the ills plaguing Castilian society. It was, at the same time, a manifestation and a reason for most of its economic upheavals. As the sources of income diminished because of bad weather, demographic decline and shcer mismanagement, the pressure on available sources of revenue increased. Tax resistance, sometimes to the point of armed confrontation, and tax collection often, as has been seen, carried by force became the stuff of everyday life in late medieval Castile.

Alfonso XI's forceful attempts to impose his will over a rebellious nobility and a cantankerous

38. Ibidem, \# $100(15.1 .1341), \# 103(20.2 .1346)$, \# 104 (14.5.1346), \#106 (11.6.1346). municipalities did not really solve the basic problem of lawlessness. His successes, which are worth highlighting, must stand in contrast to the reality of daily life. On the eve of the Plague, Castile, in spite of Alfonso XI's policies, was a realm on the edge of doom and chaos. As we look at specific examples of this slow process of disintegration, we must do so in the context of the previous pages. I am now far more convinced of my previous assertion: that the heightening level of violence was the result of the decline in royal, ecclesiastical and seigniorial rents, and that was, in itself, the consequence of the deep economic and demographic transformation of the realm which took place in the mid-thirteenth century and afterward.

Let us begin by looking at the region of the Rioja over a period of time. Although the extant documentation is not as extensive as in other areas of northern Castile, it probably contains more accounts of disturbances and signs of the existing problems than sources anywhere else. In many respects, although a fairly rich region with an important wine production and on the main commercial network of Castile, the area around Logroño, Santo Domingo de la Calzada and Nájera suffered from its geographical location. Its proximity to the frontier with Aragón and Navarre forced a larger military presence than it was desirable or, for that matter, healthy. To the north, the Basque regions had long been the focus of rebellious nobles, and their excesses there were probably unmatched by those of other areas of Old Castile. As we have seen before, Logroño had a long running feud with Victoria over the distribution of its wine. Moreover, by the early fourteenth century the re-routing of the pilgrimage route through the San Andrés pass also affected adversely the economy of the Rioja.

A few examples from the area will suffice. The villages and lands around the monastery of Santa María la Real de Nájera had been troubled by the 
same misfortunes plaguing the rest of Castile. Already in the 1270s and afterwards, those holding the rents of the salt wells in Anana refused the rightful portion of salt to the monks. Moreover, we also find the usual disputes over woods, payments of tithes and scigniorial rights with other monasteries, their own vassals and municipal corporations. It did not help, of course, that the powerful Haro family ruled in the area. There is every indication that in the late thirteenth century Diego López de Haro had taken the village of Covacardiel from Santa María la Real, which the monastery had held for more than a century. That he agreed to return it to the monks on his death, did not make-up for the loss of income $\mathrm{e}^{34}$.

Throughout the period, the monks had a running feud with the town council of Nájera. The town's officials did not allow the monastery to bring their own wine into Nájera, even if it was for thcir own use, or to store it there without a fee. In spite of the monks complaints and the admonitions of the Castilian kings, the city council still continued to make trouble ${ }^{401}$.

In 1315, Alfonso XI or his tutors agreed to lower the number of tax payers in the localities of Ventosa and Besares in 1315 , because of the wars and the accompanying depopulation. Eleven years later, conditions had worsened. In 1326, Sancho Ferrández de Greda, tax collector in the area of Ventosa, went to the village and found it "deserted and gone to waste, its inhabitants having fled to Navarre". The 1315 assessment of 10 pecheros was retained although if there was no one there, it is hard

39. AHN. Codices, 106B, f. 33 (8.7.1282), ff $37-39$ (1.8.1282, 8.4.1285); AHN. Clero, carp. 1032, no. 4 (10.2.1270), no. $6(16.5 .1270)$, no. $16(4.3 .1298)$.

40. AHN. Códices. 106B, ff. 87-88a; AHN. Clero, carp. 1032, no. 9 (26.10.1272), no. 19 (12.3.1304), no. 20 (12.3.1304). In the last document, the conccjo forbade the monastery to bring wax as well as wine into the town without paying appropriate dues. to imagine who would pay the $\operatorname{tax}^{41}$. Indeed, these were exactly the conditions which led many small villages, around Nájera, Santa Domingo de la Calzada and Logrono (and where the villagers chose 10 remain), to build walls and ramparts and which, when assaulted by the unruly local lords, brought the municipal militia of Logroño to wage war against the nobility.

On 20 Deccmber 1323, twelve neighbors of Santa Coloma, including the village's priest and blacksmith, in their name and that of the council, swore and recognized that they were the vassals of the monastery of Santa Maria de Nájera. They also agreed to build a wall around the village and not to sell, pawn, exchange or, in any other form, alienate any of their properties to any noblemen, nun, or anyone else except to other good men of Santa Coloma. They aiso promised to prevent anyone, with the exccption of the prior of the monastery, to build a strong housc or tower in the village. Moreover, the peasants were responsible for the expense of building the wall or ramparts, for the gates and lock as well as for the maintenance and defense of the fortifications. In 1338, Alfonso XI wrote to his merinos ordering them to prevent the wall of Santa Coloma from being torn down. The violence perpetrated in the region by the rebellious Don Juan Manucl and Don Juan Núñez and the wars against Aragón and Navarre threatened Santa Coloma, but it is clcar that defending the town depended, to a large extent, on the efforts of the peasants themselves and of the few artisans in the locality $\mathrm{y}^{42}$.

41. AHN. Clero, carp. 1033, no. 6 (26.5.1326).

42. AHN. Clero, carp. 1033, no. 5 (20.12.1323), no. 15 (4.12.1338). In 1363 the prior of Santa María de Nájera took possession of Santa Coloma from the city council of Logroño which held it as security for a loan of 15,000 mrs: carp. 1033 , no. $20(12.11 .1363)$. 
Other villages were placed in similar situation. In 1314, the villagers of Leza also recognized themselves as vassals of Santa María of Nájera and promised not to allow noblemen to purchase property in their village. As those of Santa Coloma had done, they began to build a wall and a strong house. Four years later in 1318, the prior of Santa Maria exempted those of Covacardiel from dues for six years in return for their building of a wall and agrecing to defend the town. Covacardiel and the nearby town of Villa Almondar had their share of difficulties with the monastery and had been forced to request a definition of the monastery's seigniorial rights. Clearly, both these villages must have had some economic importance and commercial life, since in 1.285 their procurators complained to the king against the abuses which the magnates inflicted upon the villagers, and the king exempted them from portazgo in the region between the Duero River and the ports of the Bay of Biscay ${ }^{43}$.

While small and unimportant villages, such as Santa Coloma, or more populous and economic viable ones, as Covacardiel and Villa Almondar, seemed to have weathered the stormy first half of the fourteenth century, others were not as fortunate in the period of Alfonso XI's minority. A royal charter of 1316, drawn by Alfonso XI's tutors, reveals the real pain and effects of aristocratic violence on the pcasantry. The prior of Santa María de Nájera requested from the king a ten year remission from all taxes for his vassals in Oriemo. The peasants of Oriemo had inhabited the village of Ribafrecha until around late in 1315 or early 1316 when the village was sacked by John Ferrández de Bezla, a magnate, and his retinue. They burned the village, stole the property and destroyed the crops and gardens.

43. For Leza see AHN. Códices, 106B, ff. 113-20a (8.10.1314). For Covacardicl and Villa Almondar: AHN. Códices 106B, f. 39 (8.4.1285), ff. 133.35a (23.6.1318). Also AHN. Clero, carp. 1032, no. 4 (10.2.1270).
Ribafrecha had a strong house, which was now occupied by John Ferrández. That year, John Alfonso de Haro, a powerful magnate, together with the municipal militias of Logroño, laid siege to John Ferrández's forces. The village and the land around it were "desolate" and "yerma", and Santa María's vassals had moved clsewhere and founded a new village at Oriemo. The regents agreed to exempt the villagers in Oriemo from all taxes for 10 years, except moneda forera, every 7 years ${ }^{44}$.

The same day as the previous royal charter, 20 April 1316, Alfonso XI also granted authorization to the peasants of Oriemo to build a wall in their new village, forbidding nobleman to settle there. Although the stronghold of Ribafrecha had not prevented the attack of rebellious magnates, the crown, Oriemo's lord, the prior of Santa María, and the peasants themselves saw the building of walls and the exclusion of the nobility as the only hope of survival. This, however, did not occur until 1323, when fourteen men of Oriemo, for themselves and for the village council, recognized the lordship of the monastery, and promised to build a wall at their own cost, with the other usual obligations of not allowing fijosdalgo or other nobleman into Oriemo ${ }^{45}$.

\section{The fate of Leza}

Even those villages which escaped the turbulence of Alfonso XI's minority were not spared later cvils. The minutes of a series of meetings of the concejo of Logroño, held in the town and in the village of Leza from 11 to 16 May 1334, serve as a vivid reminder that Alfonso XI's restoration of order was littlc more than a mirage. The account, preserved among the extant documents of Santa María de Nájera, records one of those events in me-

44. AHN. Códices, 106B, ff. 125-27a (20.4.1316).

45. AHN. Códices, 106B, ff. 125-27 (20.4.1316), ff. 139.45 (23.1.1323). 
dieval life, both urban and rural, which may not have been uncommon in late medieval Castile. On early evening, Wednesday 6 May 1334, the town crier of Logroño "as was the use and custom" walked through the streets of the city, calling all the citizens to a meeting of the council to be held two days afterwards at the cemetery of the church of St. James. The choice of the cemetery as a place for the gathering as well as the numerous witnesses, almost all of them citizens of Logroño, named in the document points to the popular character of the convocation. Shopkcepers, shoemakers, blacksmiths and municipal officials were in attendance. On 11 May, Don Loys, prior of Santa María de Nájera, addressed the meeting and requested that a letter of Alfonso XI to the municipal officials of Logroño (of 20 April 1334) be read to those gathered there. In the letter, the king answered the complaints of the prior and his request for restitution of the hamlet or village of Lcza.

The story unfolded as follows: Don John Alfonso de Haro, whom we had met before fighting by the side of Logroño's militia, had taken by force the logar (hamlet, place) of Leza; he had also occupied what must have been, by then, the deserted place of Ribafrecha, overturning, in the latter place, the remains of the existing wall. After refurbishing Leza's fortifications, John Alfonso and his men used it as a base of operations to raid and scourge the surrounding countryside. The concejo of Logroño, affected by these events, called its militia, marched on Leza and took it by force of arms from John Alfonso de Haro and his company. Following the capture of Leza, Logroño's officials gave Leza to Gonzalo Iváñez de Bastán, a knight and vassal of the king, but not without requiring him first to do homage to the town authoritics for Leza and to swear to keep the hamlet in Logroño's service ${ }^{46}$.
Supported by the king's letter, the prior now requested the restitution of Leza to the monastery's lordship. The citizens of Logroño argued that they had taken Leza from John Alfonso and not from the monastery and wished to wait for the king's decision on this matter. Obviously, the city council of Logroño either did not trust the monastery to keep Lcza safe from magnate violence, or saw this as an opportunity to extend its own jurisdiction into the surrounding countryside. Thus, rather than complying with don Loys petition, the town officials promised to send procurators to the royal court to inquiry into the matter.

Two days afterwards, 13 May, the prior met again with the council officials and other citizens of Logroño at the cemetery and petitioned anew for the return of Leza. Continuing to procrastinate, the men from Logroño argued that they had given Leza to Gonzalo Ivánez to hold it in the name of the king and of the town. Since Gonzalo was not present, they could not reach a decision; therefore, he was called to Logroño as a prerequisite for any decision. On Saturday 14 May, the prior met with the town's officials and, after a re-reading of Alfonso XI's letter and in the presence of Gonzalo Iváñez de Bastán, the concejo finally ordered the restitution of Leza to the monastery. Clearly, a compromise had been reached in the intervening hours, since the prior agred to take the village back but to plan its defense with the advice of "the good men" of the town of Logroño".

Later the same day, the prior and the town officials met anew in the house of the council. The municipal authorities of Logronio wished to know in detail what plans the prior had for holding Leza against the magnates and from preventing it from becoming an outpost for magnate violence once again. The prior recognized that Leza did not produce enough income to support an armed 
contingent strong enough to deter magnate incursions. Was it perhaps prudent to destroy the wall, and thus remove the temptation of using Leza as a strategic stronghold? The officials of Logroño doubted the wisdom of such action, and thought it would not be in the king's service.

On Monday 16 May, the prior, the members of the council of Logroño, Gonzalo Iváñez and the council and the good men of Leza met first within the walls of Leza and, later in the day, outside the hamlet. At the petition of Gonzalo Ivánez, the prior forgave the men of Leza for transferring their allegiance to John Alfonso and later to Gonzalo Ivañez, and, afterwards, he received the villagers renewed pledge of vassalage and promise of defending the village against attacks by the nobility ${ }^{48}$.

In this short vignette is the kernel of the history of northern Castile in the first half of the fourteenth century. Wanton violence by the nobility was often met unsuccessfully by rudimentary attempts at surrounding mere hamlets with walls. Monasteries and city councils argued and litigated over decreasing sources of income, calling on a distant and not too effective king to favor one or the other side. The peasants shifted allegiances the best they could in an effort to survive. We must also attempt to understand the implications of these defense agreements within the context of the times and of events elsewhere in the medieval West. The extant sources do not spell out what types of wall the villagers of Covacardiel, Ribafrecha, Oriemo, and Leza built. These villages must not have exceeded one hundred inhabitants, including women and children, and it is hard to imagine they had cither the manpower or the wherewithal for such enterprises. On the other hand, the walls were not just ditches around the hamlet or earth ramparts. The

48. Ibidem. documents mention gates and locks and strong houses within the wall, all of them made of stone. Since wood was sparse throughout most of Castile and stones often plentiful, one could envision low walls of mud and stone with wood gates and iron locks - the prior or a man assigned by him was always to keep the key to the gate.

These examples, however, come from fiercely disputed fronticr areas or strategically located places. In the area of the Rioja, although close to the Navarrese and Aragonese borders, the building of walls was not a response to external threats but rather to localized internal violence, nor does it seem that any of the aforementioned hamlets were in strategic locations or saw its fortunes improved by the construction of walls. Instead, the contrary took place, and the villages or hamlets became the target for the attacks of magnates and their retinue, secking to gain strong places from which to undertake their criminal activities or to remove them as threats to their power.

\section{The Impact of Violence in Late Medieval Northern Castile: the Case of Matute}

The evidence from the Rioja and from other parts of northern Castile also reveal the topsy turvy nature of Castilian lordship and the ambivalent relationship between lords and peasants. In the midfourteenth century, regardless of how much writers such as the Infante Don Juan Manuel - himself guilty of untold violence - placed on the traditional hierarchy of society, in Castile the theoretical divisions of medieval people into those who pray, those who work and those who fight, counted for very little. The peasants of Covacardiel, Leza, Oriemo and other hamlets of northern Castile were not reluctant to take arms and to defend their property. This was certainly not the response of a frontier society (many of these villagers had been for 
centuries in the rearguard of the frontier with Islam), nor was it a momentary and unexpected explosion of peasant's wrath provoked by the havoc of war, as has been the case in France during the Jacquerie or in England in 1381. Many of the Castilian peasants had planned and worked on defense projects for more than a decade.

The language of the defensive agreements between monasteries and their vassals (peasants), even in a period of bastardized feudal relations, is filled with implications of relationships far more complex than these of mighty lords and dependent peasants. The hamlets have a corporate personality, an identity which comes clearly to the surface in those few documents which remain. As the prior don Loys and the officials of Logroño argue over the jurisdiction of Leza, at the end, it is in the village itself where the dispute is finally settled. As the town and ecclesiastical representatives gathered within and outside the walls of Leza, the local priest, the councilmen of the hamlet, and all the "vecinos" give their consent and approval to the agrcement. Only then is the village returned to Santa María de Nájera, and the peasants swear to be good vassals.

We must remember that it was the militia of Logroño without any aid from the Crown: a host of shoemakers, petty tradesmen, wine dealers, butchers and the like, which went out and wrested the village from one of the most violent and formidable lords of Castile. But, of course, from morc than three centuries, urban contingents had done just that (RUIZ, 1994; POWERS, 1988). Throughout all this, the king remains an aloof, distant and ineffectual figure. There is no indication that Alfonso Xl knew much of the problems plaguing the Rioja, except when informed by the plaintive appeals of monasteries and towns. There is no indication that, even if he did know well the nature of the problem, the crown could do much about. Royal charters were sent out, often, without even royal knowledge. Tax collectors and royal officials visited deserted or semi-deserted villages and, more often than not, joined the nobility in grasping the last coins, or the last fanega of wheat from long suffering peasants and urban dwellers, but whatever order prevailed depended more on the actions of urban militias or in the peasant's determination to defend themselves. Although such conditions are not difficult to understand for the period between 1312 and 1325, when Alfonso XI's minority brought about a state of almost complete anarchy, by 1334 , after the king's ceremonial self-crowning and anointment, one would have expected better.

Not everyone, however, fared as the inhabitants of Leza and other villagers, nor every monastery cnjoyed the protection from which Santa María de Nájera had benefitted. On 30 March 1340, at the village of Matute, the bells of the church of San Román called all the "vecinos" (citizens) and the village council: "cléricos, laymen, fijosdalgo (nobles) and labradores (farmers)" to a meeting with Doña Juana López, abbess of the Cistercian monastery of La Asunción in Cañas (near Logroño) There, the villagers of Matute requested that the number of those collecting ducs from them be set at three; they also asked that their obligations to the monastery be spelled out. Later that day, the abbess met again with the villagers and told them that she knew all of them were planning to move elsewherc. Dona Juana pleaded with the peasants to inform her if this was so and to explain why they were taking such actions. The village council answered that this was true. They wished to leave because the ${ }^{2 t}$ royal merinos and tax collectors inflicted too many abuses on them and sought to collect taxes from which they were exempted. Doña Juana asked if she had been responsible for any of these abuses, except asking for the dues which were rightfully owed to the monastery. The council agreed with her, but also complained that after the forceful extortion of the 
royal officials, there was nothing left they could give to the monastery of La Asuncion. The abbess protested that she could do nothing if the rest of the realm also paid these taxes, and that the people of Matute knew that the king was on the frontier fighting the Moors. The implication being, of course, that Alfonso XI required the monies for dcfense. Nevertheless, she agreed to travel to the royal court and to beg mercy from the king in the name of the council of Matute. She asked them not to leave the village and threatened to take all the lands in Matute if they did.

We hear nothing more about Matute until 26 November 1351. That day, after a long inquest, a lengthy brief was recorded. For eleven years, since 1340 , the petty-noblemen and peasants of Matute had refused to pay a single penny or the customary contributions of bread and hens to the monastery. Finally, the abbess, by then a certain doña Teresa de Leyva, sought help from the bishop of Calahorra, who excommunicated and anathematized all the villagers for their refusal to fulfill their obligations. The 1351 document also reports the suspension of these ecclesiastical punishments by Diego Pérez de Trecino, bachelor in decretals, canon and sexton of Armenia and vicar of the bishop of Calahorra, in return for the villager's payment of 2,500 $\mathrm{mrs}$. to the abbess: the tax arrears of the past eleven years ${ }^{40}$.

49. AHN. Clero 1025 , no. 18 a $(30.3 .1340)$; no. 19 (26.11.1351).

\section{Bibliography}

ACB - Archivo de la Catedral de Burgos.

AHN - Archivo Historico Nacional, Madrid.

AMB - Archivo Municipal de Burgos, Burgos.

ASENJO, María. Segovia. La Ciudad y su Ticrra a Fincs del
The pleading tone, almost a feeling of impotence, in the abbess requests, followed by the refusal of the peasants to pay for more than a decade is not exclusive to the Rioja, nor to the period. Clearly, peasants never paid their dues promptly or gladly in Castile or anywhere else in the Middle Ages, or for that matter today. Their protestations of bureaucratic excesses could have contained, of course, that bit of exaggeration to which all taxpayers are so prone, but the numerous threats to move, refusal to pay, and the types of similar complaints which we find in this period point once again to a realm, or at least a region in the realm almost on the edge of anarchy.

In northern Castile, in the midst of a severe structural crisis, the violence of the powerful against the weak, of the agents of the crown against the citizens of the realm was part of an inexorable and fatal cycle: economic crisis, demographic decline, reduction in the sources of income, increase in violence. Against this tide of armed aggression, the threats to leave a lordship which provided no protection (a threat often carried out in practice), the refusal to pay rents and taxes, and, finally, the building of walls and strong gates were the ways in which the weak and oppressed articulated its resistance. The conditions and circumstances change, but the methods of resistance, of expanding, even if only minimally, our economic and political autonomy remain the same. They are similar to those employed throughout the world today.

Mcdicvo. Segovia, Diputación Provincial de Segovia, 1986.

BALLESTEROS, A "Burgos y la rebelión del Infante Don Sancho". Boletin de la Real Academia de la Historia, 119, 1946. 
BALLESTEROS, Mercedes Gabrois de. Historia del Rcinado de Sancho IV de Castilla. 3 vols. Madrid, Tipografía de la Revista de Archivos, Bibliotecas y Museos, 19221928. 3 vols.

BECERRO - Libro becerro de las betictrías. Estudio y texto crítico. Ed. G. Martinez Díez, León, Centro de Estudios e investigaciones "San Isidoro", 1981. 3 vols.

CHRONICÓN de Cardeña. In: España Sagrada. Madrid, Flores, 1767, vol. 23.

COLECCIÓN Diplomatica de CuCllar. Ed. Antonio Ubietn Arteta. Segovia, Diputación Provincial de Segovia, 1961.

COLECCIÓN Documental de Alfonso XI. Ed. Esther González Crespo, Madrid, Complutense, 1985.

CORTES de los Antiguos Rcinos de Lcon y Castilla. 5 vols. Madrid, Rivadeneyra, 1861-1863.

DILLARD, H. Daughters of the Reconquest. Women in Castilian Town Socicty. Cambridge, CUP, 1984.

DOCUMENTACION Medicval de Avila. Ed. A. Barrios Garcia. Salamanca, Universidad de Salamanca, 1981.

FUENTES para la Historia de Castilla. 3 vols. Ed. L. Serrano. Valladolid, G. del Amo, 1906-1910.

FMCL - Fuentes Medicvales Castellano-Leonesas. Ed. J. J.Garcin. Burgos, F, Javier Peña et alii, J.M. Garrido, $1983 \mathrm{ss}$.

GARCIA RAMILA, I. "Ordenamiento de Posturas y Otros Capitulos Gencrales Otorgados a la Ciudad de Burgos por el Rey Alfonso X". Hispania, 19, 1945.

HUIZINGA, Johan. The Waning of the Middle Ages. New York, Anchor, 1954.

MORETA VELAYOS, S. Malhechorcs Feudales: Violencia, Antagonismos y Alianzas de Clases en Castilla, Siglos XIII-XIV. Madrid, Cátedra, 1978.

MÚÑOZ Y ROMERO, T. De Fucros Municipales y Cartas Pucblas. Madrid, 1847.

NIRENBERG, David. Commtnitics of Violence. Princeton, PUP, 1996.
OÑA - Colección diplomatica de San Salvador de Oña. Ed. J. Alamo, 2 vols. Madrid, CSIC, 1950-1951.

OSMA. LOPERRAEZ CORVALÁN, Juan. Descripción Historica del Obispado de Osma. 3 vols. Madrid, Imprenta Real, 1788.

POWERS, J.F. A Society Organized for War. The Ibcrian Municipal Militias in the Middle Ages, 1000-1284. Berkeley, University of California Press, 1988.

RÁMILA, I. García. "Ordenamiento de posturas y otros capítulos generales otorgados a la ciudad de Burgos por el rey Alfonso X". Hispania, XIX, 1945, pp. 207, 213, 215.

RECUELL des chartes de l'abbaye de Silos. Ed. M. Ferotin. Paris, Imprimerie Nationale, 1897.

RUCQUOI, Adeline. Valladolid en la Edad Mcdia. 2 vols. Valladolid, Junta de Castilla y León, 1987.

RUGGEIRO, Guido. Violence in Early Renaissance Venice. New Brunswick, NJ, Rutgers Universily Press, 1980.

RUIZ, T. F. Crisis and Continuity: Land and Town in Latc Mcdieval Castille. Filadélfia, University of Pennsylvania Press, 1994.

"Elite and Popular Culture in Latc FifteenthCentury Castilian Festivals: The case of Jaen". In: WALT, B. Hana \& REYERSON, K. (cds.). City and Spetacle in Mcdicval Europe. Minneapolis, University of Minnesoln Press, 1994.

"Feslivités, Couleurs et Symboles du Pouvoir". Annales ESC, 46, 1991.

"The Transformation of the Castilian Municipalities". Past and Prescnt, 77, 1977.

. "Unsacred Monarchy: The Kings of Castile in the Late Middle Ages. In: WILENTZ, S. (ed.). Rites of Power. Symbolism, Ritual and Politics Since the Middlc Ages. Filadélfia, University of Pennsylvania Press, 1985.

VELAYOS, Salustiano Morcta. Malhechores Feudales: Violencia, Antagonismos y Alianzas de Clases en Castilla, siglos XIII-XIV. Madrid, 1978.

Endereço do Autor: Brooklyn College of The City University of New York - 2.900 Bedford Avenue - Brooklyn - New York - 11210-2889 